Article

\title{
Functional Analysis of the Acinetobacter baumannii XerC and XerD Site-Specific Recombinases: Potential Role in Dissemination of Resistance Genes
}

\author{
David L. Lin ${ }^{1,2}$, German M. Traglia ${ }^{3}$, Rachel Baker ${ }^{2}$, David J. Sherratt ${ }^{2}{ }^{\circledR}$, \\ Maria Soledad Ramirez ${ }^{1}$ (D) and Marcelo E. Tolmasky ${ }^{1,2, *(D)}$ \\ 1 Center for Applied Biotechnology Studies, Department of Biological Science, California State University \\ Fullerton, Fullerton, CA 92831, USA; davlin0916@gmail.com (D.L.L.); msramirez@Fullerton.edu (M.S.R.) \\ 2 Department of Biochemistry, University of Oxford, Oxford OX1 3QU, UK; \\ rachel.baker@bioch.ox.ac.uk (R.B.); david.sherratt@bioch.ox.ac.uk (D.J.S.) \\ 3 Departamento de Desarrollo Biotecnológico, Instituto de Higiene, Facultad de Medicina, Universidad de la \\ República (UDeLaR), Montevideo 11600, Uruguay; gertra13b@gmail.com \\ * Correspondence: mtolmasky@fullerton.edu
}

Received: 12 June 2020; Accepted: 11 July 2020; Published: 13 July 2020

\begin{abstract}
Modules composed of a resistance gene flanked by Xer site-specific recombination sites, the vast majority of which were found in Acinetobacter baumannii, are thought to behave as elements that facilitate horizontal dissemination. The A. baumannii xerC and xerD genes were cloned, and the recombinant clones used to complement the cognate Escherichia coli mutants. The complemented strains supported the resolution of plasmid dimers, and, as is the case with E. coli and Klebsiella pneumoniae plasmids, the activity was enhanced when the cells were grown in a low osmolarity growth medium. Binding experiments showed that the partially purified A. baumannii XerC and XerD proteins ( XerC $_{\mathrm{Ab}}$ and $\mathrm{XerD}_{\mathrm{Ab}}$ ) bound synthetic Xer site-specific recombination sites, some of them with a nucleotide sequence deduced from existing $A$. baumannii plasmids. Incubation with suicide substrates resulted in the covalent attachment of DNA to a recombinase, probably $\mathrm{XerC}_{\mathrm{Ab}}$, indicating that the first step in the recombination reaction took place. The results described show that $\mathrm{XerC}_{\mathrm{Ab}}$ and $\mathrm{XerD}_{\mathrm{Ab}}$ are functional proteins and support the hypothesis that they participate in horizontal dissemination of resistant genes among bacteria.
\end{abstract}

Keywords: site-specific recombination; carbapenemase; ESKAPE; Acinetobacter; plasmid; Xer; dif; pdif; Re27; gene transfer; gene dissemination; horizontal dissemination; horizontal transfer

\section{Introduction}

Site-specific recombination mediated by the tyrosine recombinases XerC and XerD (XerCD SSR) participates in a wide array of genetic processes in bacteria. After activation by FtsK, XerC and XerD catalyze the resolution of dimeric chromosomes formed by homologous recombination as a consequence of repaired, broken, or stalled replication forks [1-3]. XerCD SSR is critical for stabilization of numerous plasmids by resolving multimers that otherwise would lead to segregational instability [4,5]. In this case, the recombination reaction requires the presence of architectural proteins, like PepA and ArgR or ArcA, to form of a synaptic complex that acts as a topological filter, permitting the resolution but not formation of multimers [6]. At least for some Escherichia coli and Klebsiella pneumoniae plasmids, XerCD SSR activity levels depend on the osmolarity of the environment that produce modifications in the supercoiling density [7-10]. Many genetic elements take advantage of XerCD SSR to integrate into the bacterial chromosome. These elements, the vast majority of them phages, are known as IMEX (Integrative Mobile Elements that integrate through XerCD SSR), 
of which three different classes have been described to date [11-15]. XerCD SSR also participates in plasmid evolution as the mechanism of resolution of cointegrates formed between different plasmids by recombination at the oriT sites [16-18]. More recently, resistance genes residing in Acinetobacter baumannii plasmids were found flanked by XerC- and XerD-like binding sites (XerC/D binding sites), also referred to as Re27 or pdif $[19,20]$. The common presence of these Xer modules (XerC/D binding sites-resistance gene-XerC/D binding sites) led to the proposal that these elements play an important role in the horizontal dissemination of resistance genes [19,21-26]. The interest in the Xer modules was enhanced because many of them include carbapenemase genes like $b l a_{\mathrm{OXA} 24 / 40}-$ like, which confer A. baumannii, a member of the ESKAPE group of bacteria [27], the ability to resist some of the last-line antibiotics [21-25,28]. Xer modules have also been recently found in bacteria other than Acinetobacter and including genes other than $b l a_{\mathrm{OXA} 24 / 40}-$ like. These findings suggested that XerCD SSR may play a more general role in horizontal dissemination of different gene classes among multiple bacteria $[19,23,26]$. Among the genes found within these modules are $b l a_{\mathrm{OXA}-58}$; the $b l a_{\mathrm{OXA}-143}-1$ ike $b l a_{\mathrm{OXA}-253}$; the tetracycline resistance gene tet39; the macrolide resistance genes $m s r E$ and $m p h E$; the chromium resistance genes $\operatorname{ch} r A$ and $\operatorname{chrB}$; the organic hydroperoxide resistance genes ohr/ohrR; the transport-related genes, such as sulP and kup; the tellurium resistance ter $C$; and toxin-antitoxin (add) genes [19,23,26,29-31]. Some of them, like ohr/ohrR, chrA, chrB, sulP, kup, and add, were found in different Acinetobacter species [30], and bla $a_{\mathrm{OXA}-58}$ was found in Proteus mirabilis [26,32].

Most of the evidence of the involvement of XerCD SSR in gene mobilization in Acinetobacter was inferred from analysis of nucleotide sequences. The only indirect experimental evidence of Xer recombination in Acinetobacter was obtained after two A. baumannii plasmids were introduced in A. nosocomialis, where they formed a cointegrate by recombination at the XerC and XerD binding sites [33]. In this work we report the cloning and functional characterization of the A. baumannii XerC and $\operatorname{XerD}\left(\operatorname{XerC}_{\mathrm{Ab}}\right.$ and $\left.\mathrm{XerD}_{\mathrm{Ab}}\right)$.

\section{Results}

\subsection{Cloning and Complementation Analysis of A. baumannii Xer Recombinases}

XerC and XerD proteins are characterized by possessing two domains, the $\mathrm{C}$ - and $\mathrm{N}$-terminal, attached by a linker $[34,35]$. The C-terminal domains recognize the outer nucleotide sequences of their binding sites, including the catalytic amino acids, and participate in recombinase-recombinase interactions that coordinate their activity (Figure 1) $[34,36,37]$. The main N-terminal domains' role is the recognition and binding to the inner segment of the binding sites (boxed in Figure 1) [38]. XerC and XerD control their catalytic activity through interactions where the C-terminal portion of one of the proteins (donor) contacts the other (acceptor) in a donor-acceptor fashion. Amino acids at the donor C-terminal region interact with a stretch of three amino acids in the acceptor (boxed in gray in Figure 1), producing a conformational change that activates the latter [36]. This interaction produces a modification in the folding of the recipient protein that positions the catalytic amino acid residues for recombination to proceed [36]. The recipient amino acids in the E. coli XerC and XerD proteins are ESS and NHG, respectively (Figure 1) [34,36]. The XerC and XerD C-terminal regions that include the tripeptide and four catalytic amino acids are known as motif II (boxed in yellow in Figure 1) [35,36]. Recombination at some sites like the chromosome's dif occurs through sequential activation of the recombinases where one catalyzes the exchange of the first pair of strands to form a Holliday junction, and then the activation of the second completes the reaction [1]. In other cases, like the ColE1 plasmid cer [39] or the pJHCMW1 plasmid mwr [40], XerD is needed to activate XerC, which catalyzes the formation of the Holliday junction, which is then processed independently of XerD, most probably by DNA replication $[9,10,41,42]$. 

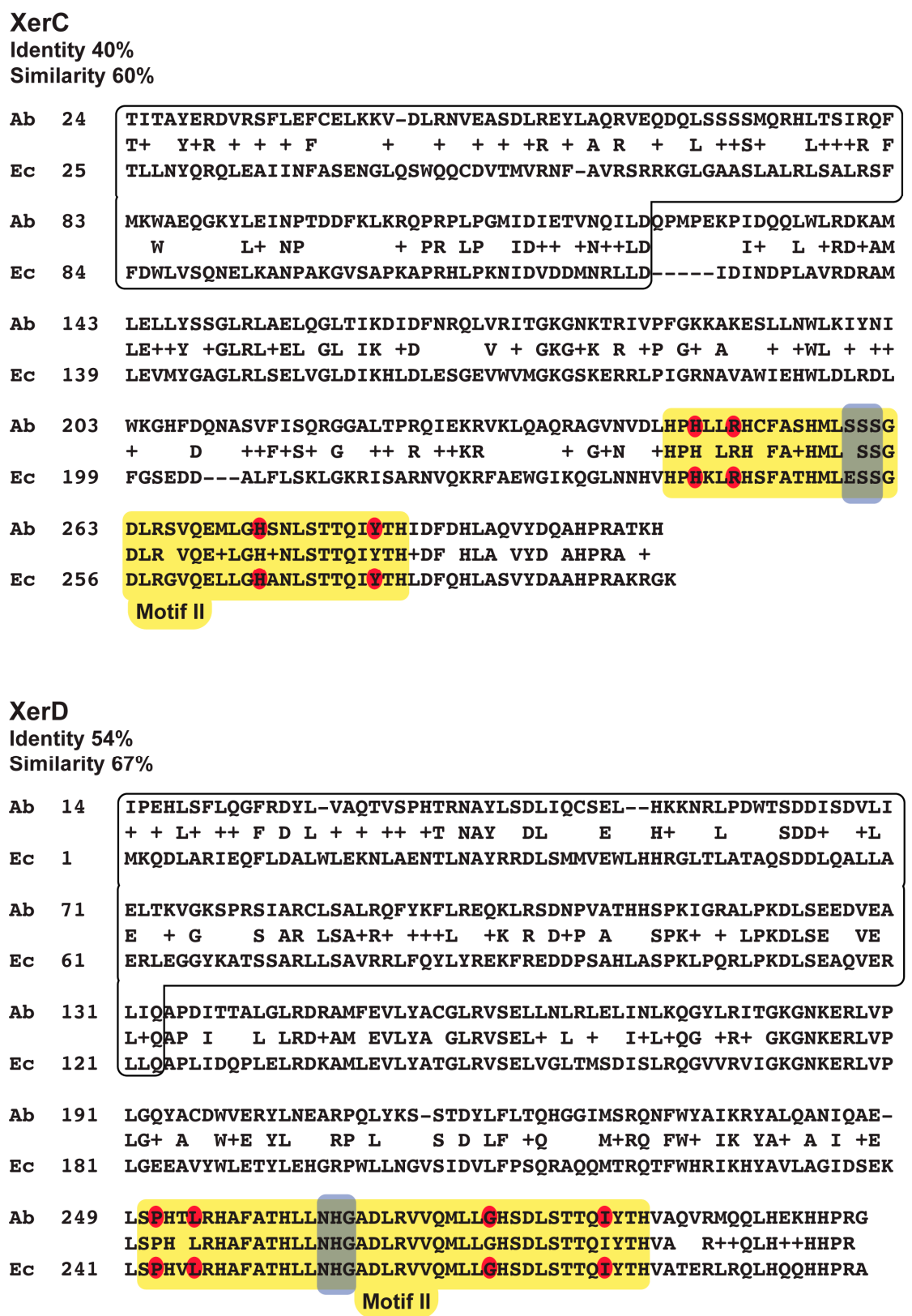

Figure 1. Alignment of the amino acid sequences of the A. baumannii and E. coli XerC and XerD. Catalytic, conserved amino acids are highlighted in red. The motif II is indicated by a solid yellow box. The tripeptides that act as acceptor in the donor-acceptor interaction with the C-terminal end of the partner protein are highlighted inside a solid gray box. The $\mathrm{N}$-terminal region is boxed. Amino acid sequences are from accession numbers NP_418256.1 (E. coli MG1655 XerC), NP_417370.1 (E. coli MG1655 XerD), [43], VCCO00000000 (A. baumannii A118 XerC and XerD) [44].

The amino acid sequences of all $\mathrm{XerC}_{\mathrm{Ab}}$ and $\mathrm{XerD}_{\mathrm{Ab}}$ proteins deposited in GenBank were compared and they share high identity (Supplementary Material, Figure S1). Although the overall XerC and XerD amino acid sequences from E. coli and A. baumannii share low identity (40\% and $54 \%$ identity, respectively), there is a higher degree of identity and similarity at their motif II regions. Figure 1 shows a comparison of the E. coli and A. baumannii XerC and XerD amino acid sequences. The XerD motif II amino acid sequences are nearly identical, and there is some divergence in the XerC amino acid sequences of the same region, including one of the amino acids in the tripeptide that interacts with XerD. Nonetheless, the amino acid sequences are close enough to expect that the heterologous proteins can interact. Then, we hypothesized that at least partial activity will be observed 
in complementation experiments where the A. baumannii enzyme is introduced in the corresponding E. coli mutant. A similar approach was used before to characterize XerCD SSR in K. pneumoniae [7].

The $x e r C_{\mathrm{Ab}}$ and $x e r D_{\mathrm{Ab}}$ genes were cloned and the recombinant clones, pMSR1 and pMSR2, were transferred to the corresponding E. coli mutants to assess their recombination activity in the plasmid dimer resolution assays. E. coli $\mathrm{DS} 981 \mathrm{XerC}_{\mathrm{Ab}}$ and $\mathrm{DS} 9028 \mathrm{XerD}_{\mathrm{Ab}}$ were transformed with dimers of the plasmid pKD3 and cultured overnight in medium containing $0.5 \%$ (high osmolarity) or no $\mathrm{NaCl}$ added (low osmolarity) before extracting the plasmid DNA. Analysis of the plasmid content from both strains showed similar results (Figure 2). While resolution was almost undetectable in cells growing in a high osmolarity medium, most of the plasmid DNA was found in its monomeric form in cells growing in a low osmolarity medium (Figure 2). These results indicated that both $\operatorname{XerC}_{\mathrm{Ab}}$ and $\operatorname{XerD}_{\mathrm{Ab}}$ were active in E. coli. The differences in levels of resolution when the cells were cultured in a high or low osmolarity medium were not surprising. Resolution of plasmid dimers at many XerCD target sites is dependent on the osmolarity of the growth medium [8,45]. Modifications in the osmolarity of the environment induce changes in the topology of the plasmid molecules making them more suitable substrates [10].

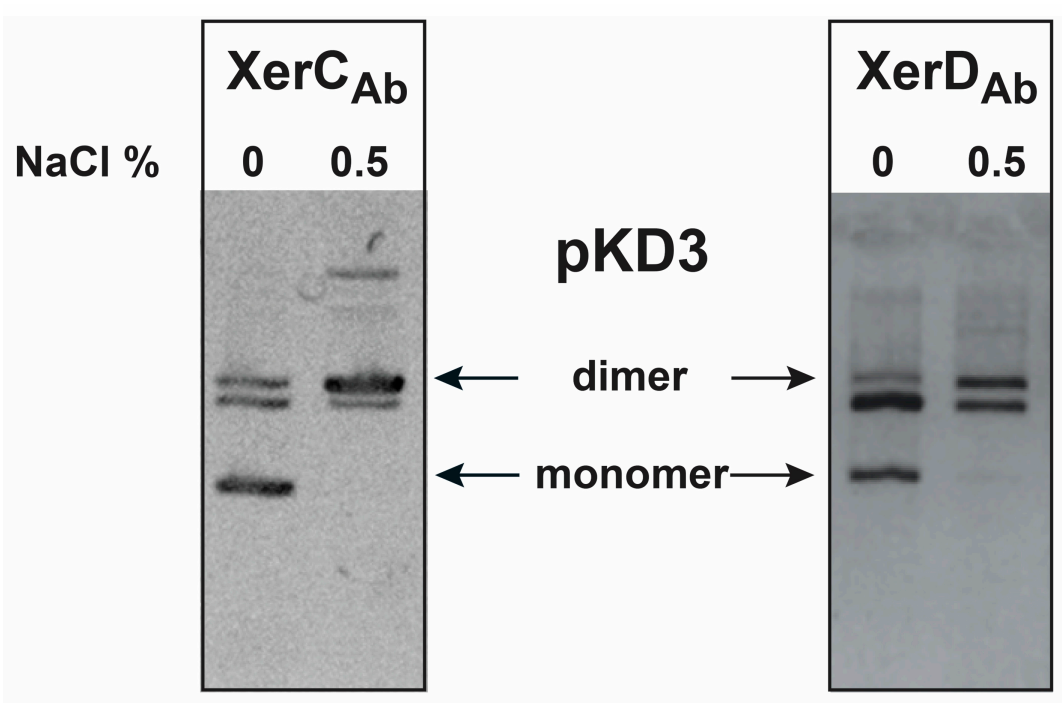

Figure 2. Resolution of plasmid dimers. Dimers of the plasmid pKD3 were introduced by transformation into E. coli DS981XerC $\mathrm{Ab}_{\mathrm{Ab}}$ or E. coli DS99028XerD $\mathrm{Ab}$. The cells were cultured overnight in a low or high osmolarity medium in the presence of $100 \mu \mathrm{g} / \mathrm{mL}$ of ampicillin. Plasmid DNA was isolated and subjected to agarose gel electrophoresis. The bands below the dimer correspond to the complementing plasmid. The position of migration of the dimers and monomers are indicated to the sides.

\subsection{Binding of A. baumannii Xer Recombinases to XerC/D Binding Sites}

Acinetobacter plasmids often include clinically relevant resistance genes, such as $b l a_{\mathrm{OXA}-24}$ or its close relative $b l a_{\mathrm{OXA}-72}$, flanked by XerC/D binding sites. Although originally these were structures uniquely found in A. baumannii, further studies showed that other genes were part of similar structures found in Acinetobacter or other genera [19-26,28-31]. These findings led to propose that Xer modules (XerC/D binding sites-resistance gene-XerC/D binding sites) are elements that facilitate the horizontal dissemination of resistance genes by XerCD SSR. However, this hypothesis is mostly based on nucleotide sequencing analyses. The first step in XerCD SSR is the cooperative attachment of XerC and XerD to the putative XerC/D binding sites. To test if $\operatorname{XerC}_{A b}$ and $X_{e r D} D_{A b}$ bind to the appropriate sites, oligodeoxynucleotides were designed taking into consideration the XerC/D binding sites identified in the A. baumannii plasmid pMMCU1 [21,46]. The arrangement XerC/D binding site-XerC/D binding site- $b l a_{\text {OXA-24 }}-$ XerC/D binding site was used to identify the potential nucleotide sequence of the XerC/D binding sites of two hypothetical DNA molecules that could have originated the arrangement found in pMMCU1 after XerCD SSR. Figure 3 shows the nucleotide sequences of the hypothetical 
original XerC/D binding sites and the Xer recombination/replication events that could have taken place. This recombination pathway has been proposed for reactions mediated by Xer as well as for other recombination systems such as the integration of gene cassettes catalyzed by IntI $112,13,47,48]$. In this pathway, one of the recombination sites is generated by formation of a hairpin between two XerC/D binding sites located in opposite orientations (see Figure 3). In the hypothetical molecule shown in black in Figure 3, the sequences that form the hairpin are not perfectly complementary. Therefore, to test binding of $\mathrm{XerC}_{\mathrm{Ab}}$ and $\mathrm{XerD}_{\mathrm{Ab}}$, two oligonucleotides were synthesized, one conserving the predicted mismatches (ODN1) and another one fully complementary (ODN2) (Table 1; see also Figures 3 and 4). Another tested oligodeoxynucleotide, ODN3 (Table 1), has the potential XerC and XerD binding regions found in at least 100 A. baumannii plasmids (as determined by BLASTN) and in the A. baumannii dif locus [49].
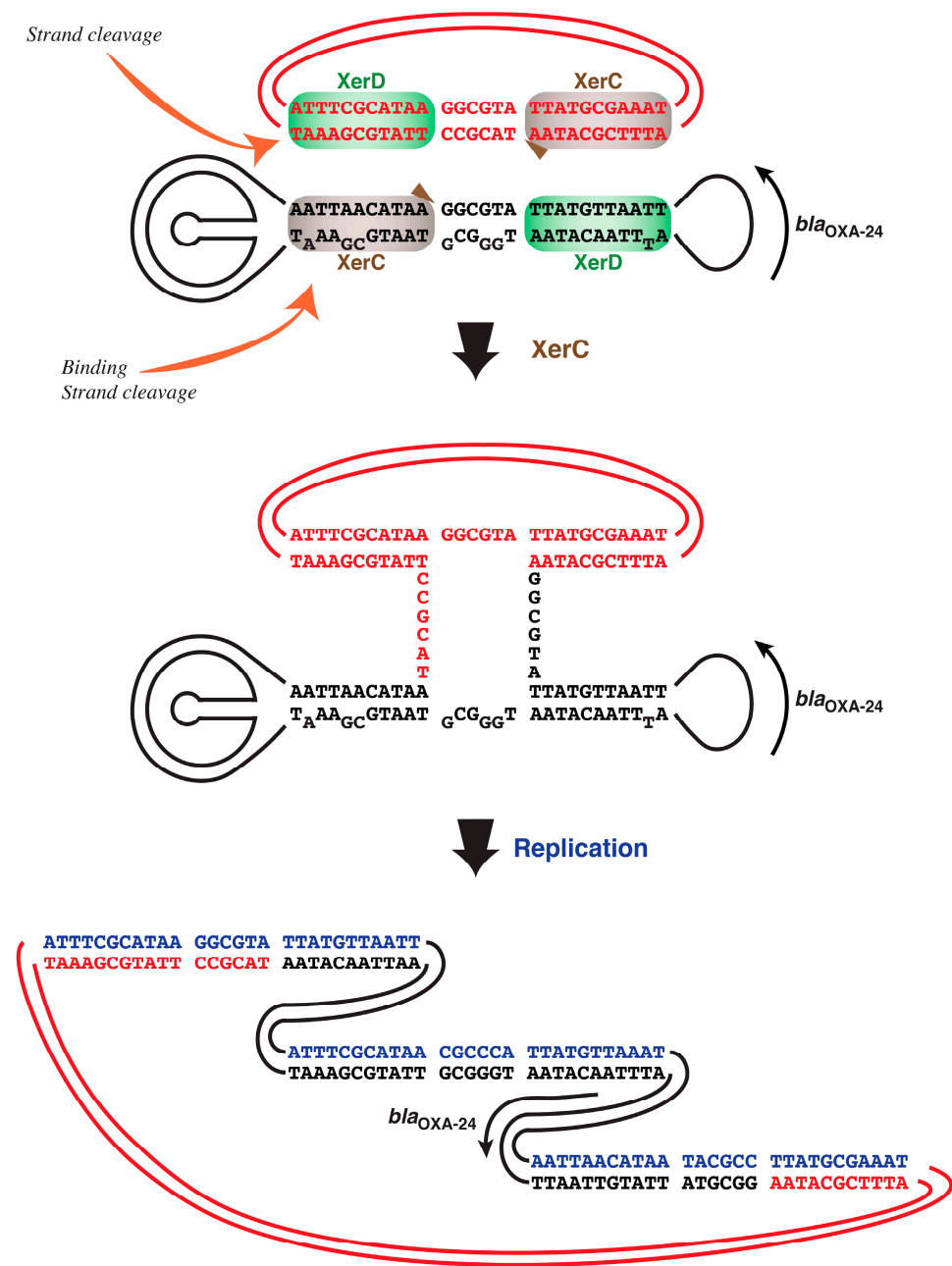

Figure 3. Hypothetical generation of the XerC/D binding sites found in the plasmid pMMCU1. The diagram shows a hypothetical recombination/replication process between two DNA molecules that produced the structure found in pMMCU1. The molecule represented in black includes blaOXA-24 flanked by XerC/D binding sites in opposite orientations. As a consequence, both strands can fold into imperfect hairpin structures that create XerC/D binding sites. The red molecule includes a XerC/D binding site that recombines with that formed by the black molecule hairpin. Blue nucleotides are those in the newly replicated strand. The nucleotide sequences and arrangement of the plasmid at the bottom are those of the plasmid pMMCU1 (accession number GQ342610) [21]. Orange arrows show the experiments performed using the oligonucleotides pointed. 
Table 1. Oligonucleotides used in the binding and cleavage assays.

\begin{tabular}{lc}
\hline Name & sequence \\
\hline ODN1 & A(A/A)TT(A/G)(A/C)CATAAG $(G / G)(C / C) G(T / C)(A / A) T T A T G T T A A T T$ \\
\hline ODN2 & AATTAACATAAGGCGTATTATGTTAATT \\
\hline ODN3 & ACTTCGTATAATCGCCATTATGTTAAAT \\
\hline ODN4 & ATTTCGCATAAGGCGTATTATGCGAAAT \\
\hline ODN5 & AATTAACATAAGGCGTATTATGTTAATT \\
\hline
\end{tabular}

Only the top strand is shown in the table. Nucleotides in parenthesis indicate mismatched positions. Phosphorothioate residues are underlined.

Figure 4 (Panels A, B, and C) shows that both $\mathrm{XerC}_{\mathrm{Ab}}$ and $\mathrm{XerD}_{\mathrm{Ab}}$ cooperatively bound the $\mathrm{XerC} / \mathrm{D}$ binding sites tested. $\mathrm{XerC}_{\mathrm{Ab}}$ showed a weak binding capability when tested in the absence of $\mathrm{XerD}_{\mathrm{Ab}}$, a property that is usually observed with Xer recombinases from other bacteria [50].
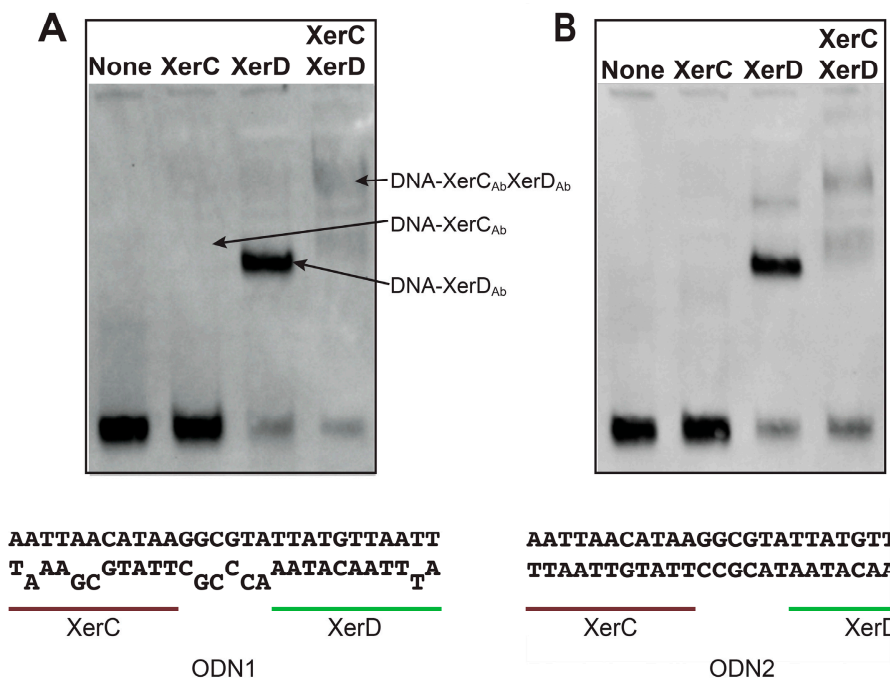

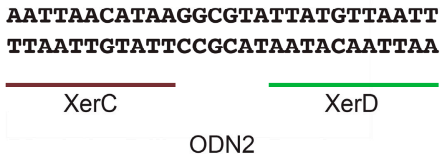

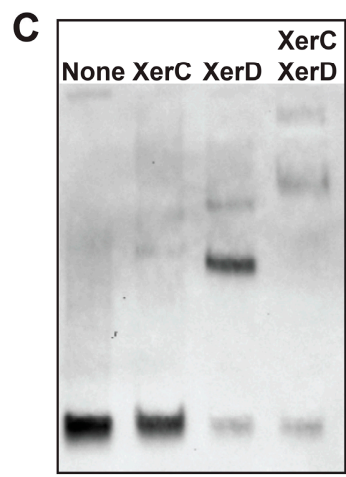

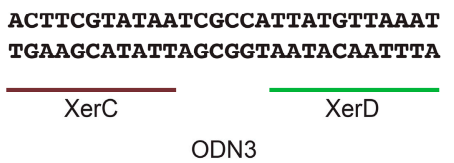

Figure 4. $\mathrm{XerC}_{\mathrm{Ab}}$ and $\mathrm{XerD}_{\mathrm{Ab}}$ binding to recombination sites. Labeled oligodeoxynucleotides were incubated in the absence or presence of the proteins indicated at the top. The products were separated by electrophoresis in an $8 \%$ polyacrylamide gel and treated as described in Materials and Methods. The nucleotide sequences of the potential Xer recombination sites tested are shown below the gels. (A) XerC and XerD binding sites identical to dif and numerous A. baumannii plasmids. (B,C) Matched and mismatched sites from the progenitor black molecule, respectively (see Figure 3).

\subsection{A. baumannii Xer Recombinases-Mediated Strand Exchange}

After the binding of XerC and XerD to their respective binding sites, the following step in the recombination reaction is the strand exchange, which requires that the DNA is cleaved and covalently bound to a tyrosine residue in the recombinase (Figure 5). The two putative XerC/D binding sites in the pMMCU1 predecessor molecules shown in Figure 3 were utilized in suicide substrate cleavage assays. The top strand, the one digested by $\mathrm{XerC}$, was synthesized with a phosphorothioate residue at the point of cleavage. Therefore, the Xer recombinase forms an irreversible covalent bond with the $3^{\prime}$-end of the top oligodeoxynucleotide containing the sulfhydryl group from the $5^{\prime}$-end of the nick. Incubation of both substrates with $\operatorname{XerC}_{\mathrm{Ab}}$ and $\mathrm{XerD}_{\mathrm{Ab}}$ followed by heat denaturation produced a high molecular weight band indicating that a Xer recombinase, presumably XerC, is covalently bound to the substrate (Figure 5). These results demonstrated that the A. baumannii XerC and XerD proteins are capable of mediating the recombination reaction necessary to facilitate dissemination of genes flanked by the XerC/D binding sites. 

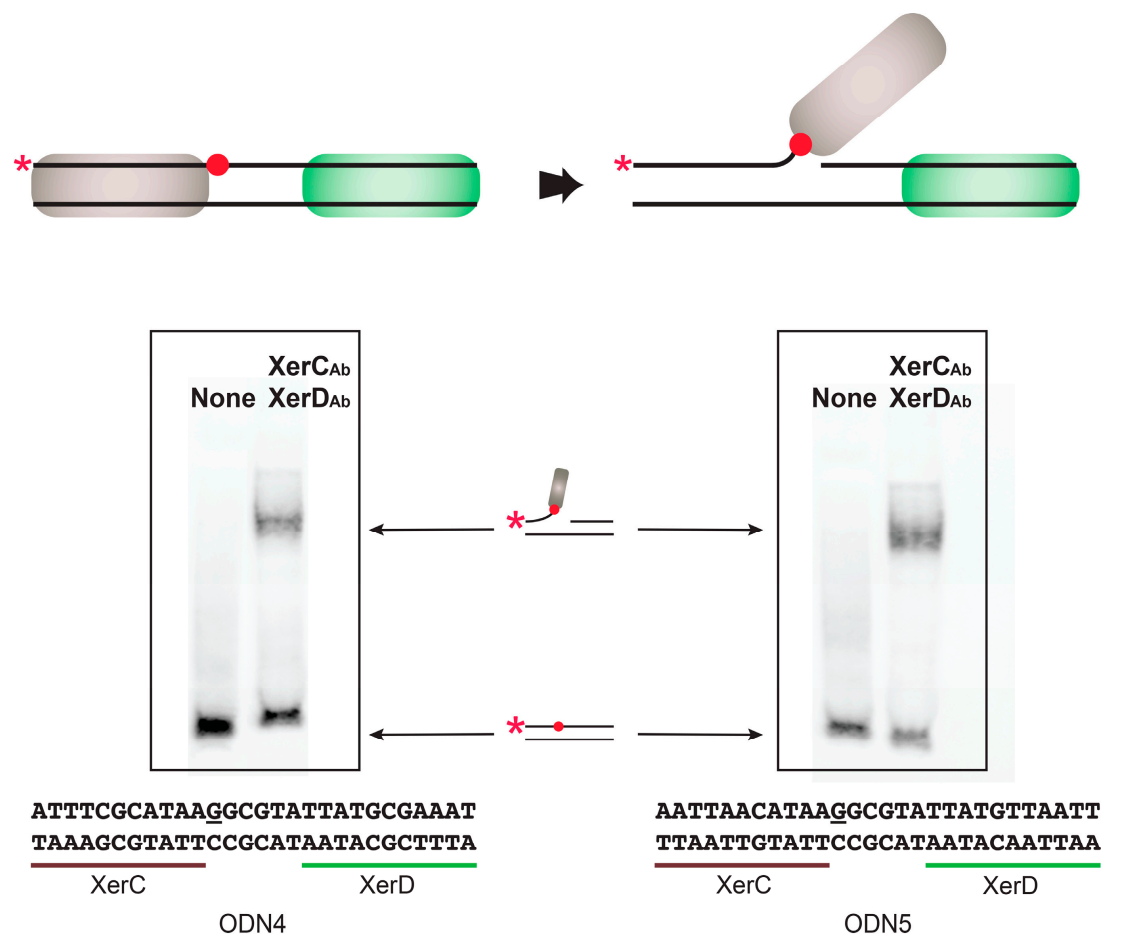

Figure 5. In vitro cleavage of the Xer recombination sites. The substrate double-stranded oligonucleotides include a phosphorothioate analog (underlined, red dot) to trap the DNA-Xer product formed after digestion and covalent attachment to the $\mathrm{Y}$ residue of the recombinase (top). Reactions were carried out at $37^{\circ} \mathrm{C}$ for $1 \mathrm{~h}$ in the presence or absence of $\mathrm{XerC}_{\mathrm{Ab}}$ (brown) and $\mathrm{XerD}_{\mathrm{Ab}}$ (green). Samples were heated at $95{ }^{\circ} \mathrm{C}$ for $5 \mathrm{~min}$ and subjected to $1 \%$ sodium dodecyl sulfate- $8 \%$ polyacrylamide gel electrophoresis. The asterisk represents the $5^{\prime}$-end biotinylation. The bands were visualized as described in Materials and Methods.

\section{Discussion}

XerCD SSR is now known to play numerous biological roles, such as ensuring the survival of a substantial percentage of individuals in a bacterial population that suffered dimerization of the chromosome, unlinking the chromosome catenanes [51,52], preventing plasmid segregational instability that would result if dimer formation remains unresolved [4,5], catalyzing integration of IMEXs into the bacterial chromosome [12-14], and participating in plasmid evolution using diverse mechanisms [16-18]. The analysis of nucleotide sequences of numerous plasmids and genomes, especially in A. baumannii, led to the proposal that genes flanked by the Xer site-specific recombination sites, mostly in opposite orientations, conform elements that mediate dissemination of the genes [19-26,28-31]. The role of the XerCD SSR in disseminating resistance genes, such as those coding for carbapenemases-enzymes that elevated A. baumannii to the category of one of the most important threats to human health $[28,53,54]$ - underscore the relevance of understanding XerCD SSR in this bacterium.

The functionality of $\mathrm{XerC}_{\mathrm{Ab}}$ and $\mathrm{XerD}_{\mathrm{Ab}}$ was first demonstrated by cloning of the cognate genes and using the recombinant clones to complement the E. coli mutants. The divergence in the A. baumannii and E. coli amino acid sequences was expected to result in lower than ideal levels of resolution. On the other hand, motif II showed high conservation, which permitted the interaction between the heterologous XerC and XerD to activate the recombination reaction. Dimer resolution in the complemented E. coli strains was minimal when the cells were cultured in a high osmolarity growth medium, but it was substantially higher in a low osmolarity medium. These results showed that $\mathrm{XerC}_{\mathrm{Ab}}$ and $\mathrm{XerD}_{\mathrm{Ab}}$ are functionally proficient in stabilizing plasmids by dimer or multimer resolution. As is the case for numerous plasmids [8,45], the recombination reaction was also strongly dependent 
on the concentration of osmolites in the growth medium. The resolution of dimers by XerCD SSR requires that the target site includes accessory sequences in addition to the core recombination site [6]. Instead, the target sites that flank the resistance genes in the Xer modules lack accessory sequences. To initiate a study of the recombination at these sites, $\operatorname{XerC}_{\mathrm{Ab}}$ and $\mathrm{XerD}_{\mathrm{Ab}}$ were partially purified and tested in vitro using as substrates the common Xer recombination sites or sites that were designed after theoretical reverse engineering of the arrangement found in pMMCU1 [21]. These potential Xer target sites could have originated pMMCU1 by Xer recombination (see Figure 3). All the tested sites showed cooperative binding by $\operatorname{XerC}_{\mathrm{Ab}}$ and $\mathrm{XerD}_{\mathrm{Ab}}$. They also showed low binding when only $\mathrm{XerC}_{\mathrm{Ab}}$ was present, but the binding was more efficient with $\mathrm{XerD}_{\mathrm{Ab}}$ or both proteins. This result is similar to those observed with the E. coli XerC and XerD in binding experiments using numerous target sites $[8,9,50]$. Cleavage experiments using suicide substrates showed that the proteins are active beyond binding. The cleavage and covalent bond to, most probably, XerC, proved that the predicted sites that originated the pMMCU1 Xer site-specific recombination sites arrangement are suitable substrates of the A. baumannii recombinases. XerCD SSR can occur through two-step strand exchanges or a pair of strand exchange followed by replication; in this latter case the original two molecules become cointegrated (Figure 3). In both cases, a resistance gene becomes part of a molecule with a new replicon, which could replicate in a different set of bacterial genera. As a consequence, successive rounds of recombination have the potential to greatly expand the range of bacteria that become resistant.

\section{Materials and Methods}

\subsection{Bacterial Strains and Plasmids}

The plasmids and strains used in this work are described in Table 2. E. coli DS941 possesses all the genes involved in Xer recombination. It was originally used to generate $x e r C$ and $x e r D$ mutant derivatives [55]. E. coli DS981 (DS941 xerC2::aph) (KAN ${ }^{\mathrm{r}}$ [56] and DS9028 (DS941 xerD3::fol) (TMP ${ }^{\mathrm{r}}$ ) [57] were used in complementation experiments. E. coli JC8679 (hyperrecombinogenic) [39] was used to generate plasmid dimers. A. baumannii $\mathrm{A} 118$ is a clinical isolate that was used as source of $x e r C_{\mathrm{Ab}}$ and $x e r D_{\mathrm{Ab}}$ genes [58,59]. A subscript indicates if the gene or protein is from A. baumannii or E. coli, e.g., $\operatorname{xerC}_{\mathrm{Ab}}$ or $x e r C_{\mathrm{Ec}}$. Plasmids pUC18 [60], pCR2.1 (Life Technologies Co.), and pACYC184 [61] were used as vectors in cloning experiments. Plasmid pKD3 is pUC18 with an insertion of a DNA fragment, including the Xer recombination site $m w r_{\mathrm{T}}$ [8].

\subsection{General DNA Procedures}

Bacteria were cultured in Lennox $\mathrm{L}$ broth ( $1 \%$ tryptone, $0.5 \%$ yeast extract, $0.5 \% \mathrm{NaCl}$ ), and $2 \%$ agar was added in the case of solid medium. Transformations were carried out as described by Cohen et al. [62]. Plasmid DNA preparations and DNA gel extractions were performed with the QIAprep Spin miniprep kit and QIAquick gel extraction kit, respectively (QIAGEN). Restriction endonuclease and ligase treatments were performed as recommended by the suppliers. DNA fragments containing the $x e r C_{\mathrm{Ab}}$ or $x e r D_{\mathrm{Ab}}$ genes were generated by PCR amplification with the QIAGEN Taq master mix using as a template the genomic DNA from A. baumannii A118. Amplicons were inserted in pCR2.1 and then subcloned into the EcoRI site of pACYC184. Both $x e r C_{\mathrm{Ab}}$ or $x e r D_{\mathrm{Ab}}$ were further subcloned into pBAD102 with a C-terminal 6x histidine tag for overexpression and purification. The inserts of all recombinant plasmids were sequenced to ensure accuracy. Nucleotide sequencing was performed at the DNA Sequencing Facility, Department of Biochemistry, University of Oxford.

\subsection{Protein Purification}

C-terminally tagged $\operatorname{XerC}_{\mathrm{Ab}}$ and $\operatorname{XerD}_{\mathrm{Ab}}$ with $6 \mathrm{x}$ histidine were affinity purified using TALON metal affinity resin as previously described [41]. Briefly, E. coli DS9040 (pBAD102xerC $\mathrm{Ab}_{\mathrm{Ab}}$ ) or E. coli DS9040 (pBAD102xerD $D_{\mathrm{Ab}}$ ) were cultured overnight at $37^{\circ} \mathrm{C}$ with shaking. Each culture was then diluted 1:100 and shaken at $200 \mathrm{rpm}$ at $37^{\circ} \mathrm{C}$ for $3.5 \mathrm{~h}$. At this moment, protein expression was induced by 
addition of $0.1 \%$ arabinose and incubation at $30^{\circ} \mathrm{C}$. After $4 \mathrm{~h}$, the cells were collected by centrifugation at $5000 \mathrm{rpm}$ for $20 \mathrm{~min}$ and resuspended in a buffer containing $50 \mathrm{mM}$ Tris $7.5,1 \mathrm{M} \mathrm{NaCl}$, and $10 \%$ glycerol with protease inhibitor cocktail (Sigma). The cells were lysed using a French Press and the lysate was subjected to centrifugation at $19,000 \mathrm{rpm}$ for $30 \mathrm{~min}$ at $4{ }^{\circ} \mathrm{C}$. The supernatant containing the protein of interest was mixed with TALON metal affinity resin and incubated for $1 \mathrm{~h}$. The resin was washed with a buffer containing $50 \mathrm{mM}$ Tris- $\mathrm{HCl}$ ( $\mathrm{pH}$ 7.5), $500 \mathrm{mM} \mathrm{NaCl}, 10 \%$ glycerol, and $10 \mathrm{mM}$ imidazole. The proteins were eluted by a gravity column into 8 fractions with a buffer containing $50 \mathrm{mM}$ Tris-HCl (pH 7.5), $500 \mathrm{mM} \mathrm{NaCl}, 10 \%$ glycerol, and $200 \mathrm{mM}$ imidazole. Proteins were analyzed using sodium dodecyl sulfate-15\% polyacrylamide gel electrophoresis stained with Coomassie blue to identify the fractions containing $\mathrm{XerC}_{\mathrm{Ab}}$ and $\mathrm{XerD}_{\mathrm{Ab}}$ (Supplementary Material, Figure S2). The selected fractions were pooled, dialyzed with $10 \mathrm{mM}$ Tris- $\mathrm{HCl}$ (pH 7.5) using Zeba desalting columns (ThermoFisher Scientific), and concentrated to approximately $150 \mu \mathrm{g} / \mathrm{mL}$ using Pierce protein concentrator PES columns (ThermoFisher Scientific) according to the manufacturer's recommendations.

\subsection{In Vivo Resolution Assay}

In vivo resolution assays were carried out basically as described by Pham et al. [8]. Plasmid dimers, generated using E. coli JC8679 as described previously [8], were introduced by transformation into the indicated strains. The transformant strains were cultured overnight at $37^{\circ} \mathrm{C}$ in Lennox L broth (high osmolarity) or medium containing the same concentrations of tryptone and yeast extract as the Lennox $\mathrm{L}$ broth but without the addition of $\mathrm{NaCl}$ (low osmolarity). After overnight growth, plasmid DNA was purified and analyzed by electrophoresis in a $0.7 \%$ agarose gel.

\subsection{DNA-Binding Assay}

Binding of $\mathrm{XerC}_{\mathrm{Ab}}$ and $\mathrm{XerD}_{\mathrm{Ab}}$ to the potential recombination sites were carried out as described before $[9,63]$. An oligodeoxynucleotide was $5^{\prime}$-end biotinylated using the $5^{\prime}$-EndTag DNA labeling kit. Equal volumes of equimolar solutions (in NEB Cutsmart buffer) of the labeled compound and the complementary oligodeoxynucleotide were mixed, heated at $95^{\circ} \mathrm{C}$ for $5 \mathrm{~min}$, let slowly cooldown to room temperature, and placed on ice, to generate a labeled, double-stranded XerC/D recombination site. An aliquot containing $40 \mathrm{fmols}$ of the DNA substrate was mixed with a reaction buffer $(10 \mathrm{mM}$ Tris-HCl (pH 7.5), $50 \mathrm{mM} \mathrm{KCl}, 1 \mathrm{mM}$ DTT, $25 \mathrm{ng} / \mu \mathrm{L}$ poly dI/dC, 2.5\% glycerol, $10 \mathrm{mM}$ EDTA, and $0.05 \% \mathrm{NP}-40$ ). The indicated protein (XerC, XerD, or both) was added to the reaction mix at a final concentration of $150 \mathrm{ng} / \mu \mathrm{L}$. The reaction was incubated at $37^{\circ} \mathrm{C}$ for $1 \mathrm{~h}$. Samples were analyzed using $8 \%$ polyacrylamide gel electrophoresis at $100 \mathrm{~V}$. Resolved DNA and protein complexes were transferred to a nylon membrane using the iBlot system (ThermoFisher Scientific), following the recommendation of the supplier. After the transfer, blots were cross-linked under UV light in a Stratalinker 1200 for 120 s. The blots were visualized using the Chemiluminescent Nucleic Acid Detection Module Kit (ThermoFisher Scientific). Bands were visualized by ChemiDoc XRS (BioRad).

\subsection{In Vitro Xer-Mediated DNA Cleavage}

Digestion by and covalent binding to $\mathrm{XerC}_{\mathrm{Ab}}$ was carried out using a labeled, double-stranded oligodeoxynucleotide, in which the top strand includes a phosphorothioate analog residue at the point of digestion and a $5^{\prime}$ biotin modification. When this substrate is nicked, the Xer recombinase forms a covalent bond between the $3^{\prime}$-end of the oligodeoxynucleotide containing the sulfhydryl group from the $5^{\prime}$-end of the nick and the tyrosine for the recombinase. The $5^{\prime}$-SH group is a poor nucleophile for religation, making the reaction irreversible. In these conditions, there is an accumulation of the DNA-recombinase covalent product [64]. An aliquot containing 0.8 pmols of annealed dsDNA was mixed with a buffer containing $20 \mathrm{mM}$ Tris- $\mathrm{HCl}$ (pH 7.5), $50 \mathrm{mM} \mathrm{NaCl}, 0.1 \mathrm{mM}$ EDTA, 2.5\% glycerol, and $50 \mathrm{ng} / \mu \mathrm{L}$ bovine serum albumin. Aliquots containing $\mathrm{XerC}_{\mathrm{Ab}}$ and $\mathrm{XerD}_{\mathrm{Ab}}$ were added to the reaction to a final concentration of $150 \mathrm{ng} / \mu \mathrm{L}$ of each protein and incubated at $37^{\circ} \mathrm{C}$ for $1 \mathrm{~h}$. The reactions were terminated by adding a denaturing loading buffer containing an additional $2 \%$ sodium dodecyl 
sulfate and $5 \% \beta$-mercaptoethanol. Samples were heated at $95{ }^{\circ} \mathrm{C}$ for $5 \mathrm{~min}$ and subjected to $1 \%$ sodium dodecyl sulfate- $8 \%$ polyacrylamide gel electrophoresis. The biotinylated DNA and protein complexes were transferred to a nylon membrane and visualized as described above.

Table 2. Bacterial strains and plasmids used in this study.

\begin{tabular}{|c|c|c|}
\hline $\begin{array}{l}\text { Bacterial Strain or } \\
\text { Plasmid }\end{array}$ & Relevant Characteristics, Genotype, or Phenotype ${ }^{\text {a }}$ & $\begin{array}{l}\text { Source or } \\
\text { Reference }\end{array}$ \\
\hline \multicolumn{3}{|l|}{ E. coli strains } \\
\hline DS941 & AB1157 recF143 lacI lacZ $\Delta$ M15 & [65] \\
\hline DS981 & DS941 $\operatorname{xerC}\left(\operatorname{Kan}^{\mathrm{r}}\right)$ & [56] \\
\hline DS9028 & DS941 $\operatorname{xerD}\left(\mathrm{Tmp}^{\mathrm{r}}\right)$ & [57] \\
\hline DS981XerC $_{\mathrm{Ab}}$ & DS981 (pMSR1) (Kan $\left.{ }^{\mathrm{r}} \mathrm{Tet}^{\mathrm{r}}\right)$ & This work \\
\hline DS9028XerD $_{\mathrm{Ab}}$ & DS9028 (pMSR2) $\left(\mathrm{Tmp}^{\mathrm{r}} \mathrm{Tet}^{\mathrm{r}}\right)$ & This work \\
\hline DS9040 & DS941 xerC xerD $\left(\operatorname{Kan}^{\mathrm{r}}\right.$ Gen $\left.^{\mathrm{r}}\right)$ & [34] \\
\hline JC8679 & DS945 recBC sbcA (hyperrecombinogenic) & [39] \\
\hline \multicolumn{3}{|l|}{ A. baumannii strain } \\
\hline A118 & Human clinical isolate & [58] \\
\hline \multicolumn{3}{|l|}{ Plasmids } \\
\hline pMSR1 & $x e r C_{\mathrm{Ab}}$ cloned into the pACYC184 EcoRI site $\left(\right.$ Tet $\left.^{\mathrm{r}}\right)$ & This work \\
\hline pMSR2 & $x e r D_{\mathrm{Ab}}$ cloned into the $\mathrm{pACYC184}$ EcoRI site $\left(\mathrm{Tet}^{\mathrm{r}}\right)$ & This work \\
\hline pBAD102xerC $C_{A b}$ & $x e r C_{\mathrm{Ab}}$ cloned into pBAD102 $\left(\mathrm{Amp}^{\mathrm{r}}\right)$ & This work \\
\hline pBAD102xer $D_{\mathrm{Ab}}$ & $x e r D_{\mathrm{Ab}}$ cloned into pBAD102 $\left(\mathrm{Amp}^{\mathrm{r}}\right)$ & This work \\
\hline pKD3 & $\begin{array}{l}\text { EcoRI-SacI fragment containing the pJHCMW1 mwr site with substitution C } \\
\text { to T at the ArgR binding site cloned in pUC18 }\left(\mathrm{Amp}^{\mathrm{r}}\right)\end{array}$ & [8] \\
\hline pUC18 & Cloning vector $\left(\mathrm{Amp}^{\mathrm{r}}\right)$ & [60] \\
\hline pCR2.1 & Cloning vector $\left(\mathrm{Amp}^{\mathrm{r}}, \mathrm{Kan}^{\mathrm{r}}\right)$ & ThermoFisher \\
\hline pACYC184 & Cloning vector, p15A replicon $\left(\mathrm{Chl}^{\mathrm{r}} \mathrm{Tet}^{\mathrm{r}}\right)$ & [61] \\
\hline
\end{tabular}

a Amp, ampicillin; Chl, chloramphenicol; Gen, gentamicin; Kan, kanamycin; Tet, tetracycline; Tmp, trimethoprim.

\section{Conclusions}

This article describes the biological evidence of functional XerC and XerD recombinases in A. baumannii. The proteins were cloned, partially purified, and tested in vitro to show their ability to catalyze recombination between sites recognized in the literature as putative Xer site-specific recombination sites that are part of the antibiotic resistance gene-mobilization modules postulated in the literature. This article also shows that $\operatorname{XerC}_{\mathrm{Ab}}$ and $\operatorname{XerD}_{\mathrm{Ab}}$ can participate in plasmid stability by multimer resolution.

Supplementary Materials: The following are available online at http://www.mdpi.com/2079-6382/9/7/405/s1, Figure S1: Phylogenetic trees of $\mathrm{XerC}_{\mathrm{Ab}}$ and $\mathrm{XerD}_{\mathrm{Ab}}$, Figure S2: Partial purification of $\mathrm{XerC}_{\mathrm{Ab}}$ and $\mathrm{XerD}_{\mathrm{Ab}}$.

Author Contributions: Conceptualization, M.E.T., D.J.S., and M.S.R.; formal analysis, D.L.L., G.M.T., D.J.S., M.S.R., and M.E.T.; funding acquisition, M.S.R., D.J.S., and M.E.T.; methodology, D.L.L., G.M.T., R.B., D.J.S., M.S.R., and M.E.T.; resources, M.S.R., D.J.S., and M.E.T.; writing-original draft preparation, M.E.T.; writing-review and editing, M.E.T., D.L.L., M.S.R., D.J.S. All authors have read and agreed to the published version of the manuscript.

Funding: This research was funded by Public Health Service Grants 2R15AI047115 (MET) and SC3GM125556 (MSR) from the National Institute of Health. Research in the DJS laboratory was funded by Wellcome (Investigator Award 200782/Z/16/Z). D.L.L. was partially supported by grant LA Basin Minority Health and Health Disparities Research Training Program (MHRT) T37MD001368 from the National Institute on Minority Health and Health Disparities, National Institute of Health.

Conflicts of Interest: The authors declare no conflict of interest.

\section{References}

1. Aussel, L.; Barre, F.X.; Aroyo, M.; Stasiak, A.; Stasiak, A.Z.; Sherratt, D. FtsK Is a DNA motor protein that activates chromosome dimer resolution by switching the catalytic state of the XerC and XerD recombinases. Cell 2002, 108, 195-205. [CrossRef]

2. Sherratt, D.J.; Soballe, B.; Barre, F.X.; Filipe, S.; Lau, I.; Massey, T.; Yates, J. Recombination and chromosome segregation. Philos. Trans. R. Soc. Lond. B Biol. Sci. 2004, 359, 61-69. [CrossRef] 
3. Zawadzki, P.; May, P.F.; Baker, R.A.; Pinkney, J.N.; Kapanidis, A.N.; Sherratt, D.J.; Arciszewska, L.K. Conformational transitions during FtsK translocase activation of individual XerCD-dif recombination complexes. Proc. Natl. Acad. Sci. USA 2013, 110, 17302-17307. [CrossRef]

4. Summers, D.K.; Beton, C.W.; Withers, H.L. Multicopy plasmid instability: The dimer catastrophe hypothesis. Mol. Microbiol. 1993, 8, 1031-1038. [CrossRef]

5. Colloms, S.D.; Alen, C.; Sherratt, D.J. The ArcA/ArcB two-component regulatory system of Escherichia coli is essential for Xer site-specific recombination at psi. Mol. Microbiol. 1998, 28, 521-530. [CrossRef] [PubMed]

6. Colloms, S.D. The topology of plasmid-monomerizing Xer site-specific recombination. Biochem. Soc. Trans. 2013, 41, 589-594. [CrossRef] [PubMed]

7. Bui, D.; Ramiscal, J.; Trigueros, S.; Newmark, J.S.; Do, A.; Sherratt, D.J.; Tolmasky, M.E. Differences in resolution of mwr-containing plasmid dimers mediated by the Klebsiella pneumoniae and Escherichia coli XerC recombinases: Potential implications in dissemination of antibiotic resistance genes. J. Bacteriol. 2006, 188, 2812-2820. [CrossRef] [PubMed]

8. Pham, H.; Dery, K.J.; Sherratt, D.J.; Tolmasky, M.E. Osmoregulation of dimer resolution at the plasmid pJHCMW1 mwr locus by Escherichia coli XerCD recombination. J. Bacteriol. 2002, 184, 1607-1616. [CrossRef] [PubMed]

9. Tolmasky, M.E.; Colloms, S.; Blakely, G.; Sherratt, D.J. Stability by multimer resolution of pJHCMW1 is due to the Tn1331 resolvase and not to the Escherichia coli Xer system. Microbiology 2000, 146, 581-589. [CrossRef] [PubMed]

10. Trigueros, S.; Tran, T.; Sorto, N.; Newmark, J.; Colloms, S.D.; Sherratt, D.J.; Tolmasky, M.E. mwr Xer site-specific recombination is hypersensitive to DNA supercoiling. Nucleic Acids Res. 2009, 37, 3580-3587. [CrossRef]

11. Das, B.; Martinez, E.; Midonet, C.; Barre, F.X. Integrative mobile elements exploiting Xer recombination. Trends Microbiol. 2013, 21, 23-30. [CrossRef]

12. Midonet, C.; Barre, F.X. Xer site-specific recombination: Promoting vertical and horizontal transmission of genetic information. Microbiol Spectr 2014, 2, MDNA3-0056-2014.

13. Val, M.E.; Bouvier, M.; Campos, J.; Sherratt, D.; Cornet, F.; Mazel, D.; Barre, F.X. The single-stranded genome of phage CTX is the form used for integration into the genome of Vibrio cholerae. Mol. Cell 2005, 19, 559-566. [CrossRef]

14. Campos, J.; Martinez, E.; Suzarte, E.; Rodriguez, B.L.; Marrero, K.; Silva, Y.; Ledon, T.; del Sol, R.; Fando, R. VGJ phi, a novel filamentous phage of Vibrio cholerae, integrates into the same chromosomal site as CTX phi. J. Bacteriol. 2003, 185, 5685-5696. [CrossRef] [PubMed]

15. Hassan, F.; Kamruzzaman, M.; Mekalanos, J.J.; Faruque, S.M. Satellite phage TLCphi enables toxigenic conversion by CTX phage through dif site alteration. Nature 2010, 467, 982-985. [CrossRef] [PubMed]

16. Zakharova, M.V.; Beletskaya, I.V.; Denjmukhametov, M.M.; Yurkova, T.V.; Semenova, L.M.; Shlyapnikov, M.G.; Solonin, A.S. Characterization of pECL18 and pKPN2: A proposed pathway for the evolution of two plasmids that carry identical genes for a Type II restriction-modification system. Mol. Genet. Genomics 2002, 267, 171-178. [CrossRef]

17. Tran, T.; Andres, P.; Petroni, A.; Soler-Bistue, A.; Albornoz, E.; Zorreguieta, A.; Reyes-Lamothe, R.; Sherratt, D.J.; Corso, A.; Tolmasky, M.E. Small plasmids harboring qnrB19: A model for plasmid evolution mediated by site-specific recombination at oriT and Xer sites. Antimicrob. Agents Chemother. 2012, 56, 1821-1827. [CrossRef]

18. Ramirez, M.S.; Traglia, G.M.; Lin, D.L.; Tran, T.; Tolmasky, M.E. Plasmid-mediated antibiotic resistance and virulence in gram-negatives: The Klebsiella pneumoniae paradigm. Microbiol. Spectr. 2014, 2, PLAS-0016-2013. [CrossRef]

19. Blackwell, G.A.; Hall, R.M. The tet39 determinant and the msrE-mphE genes in Acinetobacter plasmids are each part of discrete modules flanked by inversely oriented pdif (XerC-XerD) sites. Antimicrob. Agents Chemother. 2017, 61, e00717-e00780. [CrossRef]

20. Poirel, L.; Nordmann, P. Genetic structures at the origin of acquisition and expression of the carbapenem-hydrolyzing oxacillinase gene blaOXA-58 in Acinetobacter baumannii. Antimicrob. Agents Chemother. 2006, 50, 1442-1448. [CrossRef] 
21. Merino, M.; Acosta, J.; Poza, M.; Sanz, F.; Beceiro, A.; Chaves, F.; Bou, G. OXA-24 carbapenemase gene flanked by XerC/XerD-like recombination sites in different plasmids from different Acinetobacter species isolated during a nosocomial outbreak. Antimicrob. Agents Chemother. 2010, 54, 2427-2727. [CrossRef] [PubMed]

22. Grosso, F.; Quinteira, S.; Poirel, L.; Novais, A.; Peixe, L. Role of common blaOXA-24/OXA-40-carrying platforms and plasmids in the spread of OXA-24/OXA-40 among Acinetobacter species clinical isolates. Antimicrob. Agents Chemother. 2012, 56, 3969-3972. [CrossRef] [PubMed]

23. D'Andrea, M.; Giani, T.; D’Arezzo, S.; Capone, A.; Petrosillo, N.; Visca, P.; Luzzaro, F.; Rossolini, G.M. Characterization of pABVA01, a plasmid encoding the OXA-24 carbapenemase from italian isolates of Acinetobacter baumannii. Antimicrob. Agents Chemother. 2009, 53, 3528-3533. [CrossRef] [PubMed]

24. Povilonis, J.; Seputiene, V.; Krasauskas, R.; Juskaite, R.; Miskinyte, M.; Suziedelis, K.; Suziedeliene, E. Spread of carbapenem-resistant Acinetobacter baumannii carrying a plasmid with two genes encoding OXA-72 carbapenemase in Lithuanian hospitals. J. Antimicrob. Chemother. 2013, 68, 1000-1006. [CrossRef] [PubMed]

25. Tian, G.B.; Adams-Haduch, J.M.; Bogdanovich, T.; Pasculle, A.W.; Quinn, J.P.; Wang, H.N.; Doi, Y. Identification of diverse OXA-40 group carbapenemases, including a novel variant, OXA-160, from Acinetobacter baumannii in Pennsylvania. Antimicrob. Agents Chemother. 2011, 55, 429-432. [CrossRef] [PubMed]

26. Girlich, D.; Bonnin, R.A.; Bogaerts, P.; De Laveleye, M.; Huang, D.T.; Dortet, L.; Glaser, P.; Glupczynski, Y.; Naas, T. Chromosomal amplification of the blaOXA-58 carbapenemase gene in a Proteus mirabilis clinical isolate. Antimicrob. Agents Chemother. 2017, 61, e01616-e01697. [CrossRef]

27. Boucher, H.W.; Talbot, G.H.; Benjamin, D.K.; Bradley, J.; Guidos, R.J.; Jones, R.N.; Murray, B.E.; Bonomo, R.A.; Gilbert, D. $10 \times$ '20 Progress-Development of new drugs active against gram-negative bacilli: An update from the Infectious Diseases Society of America. Clin. Infect. Dis. 2013, 56, 1685-1694. [CrossRef]

28. Ramirez, M.S.; Bonomo, R.A.; Tolmasky, M.E. Carbapenemases: Transforming Acinetobacter baumannii into a yet more dangerous menace. Biomolecules 2020, 10, 720. [CrossRef]

29. Mindlin, S.; Petrenko, A.; Petrova, M. Chromium resistance genetic element flanked by XerC/XerD recombination sites and its distribution in environmental and clinical Acinetobacter strains. FEMS Microbiol. Lett. 2018, 365, fny047. [CrossRef]

30. Mindlin, S.; Beletsky, A.; Mardanov, A.; Petrova, M. Adaptive dif modules in permafrost strains of Acinetobacter iwoffii and their distribution and abundance among present day Acinetobacter strains. Front. Microbiol. 2019, 10, 632. [CrossRef]

31. Girlich, D.; Damaceno, Q.S.; Oliveira, A.C.; Nordmann, P. OXA-253, a variant of the carbapenem-hydrolyzing class D beta-lactamase OXA-143 in Acinetobacter baumannii. Antimicrob. Agents Chemother. 2014, 58, 2976-2978. [CrossRef] [PubMed]

32. Bonnin, R.A.; Girlich, D.; Jousset, A.B.; Gauthier, L.; Cuzon, G.; Bogaerts, P.; Haenni, M.; Madec, J.Y.; Couve-Deacon, E.; Barraud, O.; et al. A single Proteus mirabilis lineage from human and animal sources: A hidden reservoir of OXA-23 or OXA-58 carbapenemases in Enterobacterales. Sci. Rep. 2020, 10, 9160. [CrossRef] [PubMed]

33. Cameranesi, M.M.; Moran-Barrio, J.; Limansky, A.S.; Repizo, G.D.; Viale, A.M. Site-Specific recombination at XerC/D sites mediates the formation and resolution of plasmid co-integrates carrying a blaOXA-58- and TnaphA6-Resistance module in Acinetobacter baumannii. Front. Microbiol. 2018, 9, 66. [CrossRef] [PubMed]

34. Ferreira, H.; Butler-Cole, B.; Burgin, A.; Baker, R.; Sherratt, D.J.; Arciszewska, L.K. Functional analysis of the C-terminal domains of the site-specific recombinases XerC and XerD. J. Mol. Biol. 2003, 330, 15-27. [CrossRef]

35. Subramanya, H.S.; Arciszewska, L.K.; Baker, R.A.; Bird, L.E.; Sherratt, D.J.; Wigley, D.B. Crystal structure of the site-specific recombinase, XerD. EMBO J. 1997, 16, 5178-5187. [CrossRef] [PubMed]

36. Hallet, B.; Arciszewska, L.K.; Sherratt, D. Reciprocal control of catalysis by the tyrosine recombinases XerC and XerD: An enzymatic switch in site-specific recombination. Mol. Cell 1999, 4, 949-959. [CrossRef]

37. Spiers, A.J.; Sherratt, D.J. C-terminal interactions between the XerC and XerD site-specific recombinases. Mol. Microbiol. 1999, 32, 1031-1042. [CrossRef]

38. Ferreira, H.; Sherratt, D.; Arciszewska, L. Switching catalytic activity in the XerCD site-specific recombination machine. J. Mol. Biol. 2001, 312, 45-57. [CrossRef] 
39. Summers, D.K.; Sherratt, D.J. Multimerization of high copy number plasmids causes instability: CoIE1 encodes a determinant essential for plasmid monomerization and stability. Cell 1984, 36, 1097-1103. [CrossRef]

40. Sarno, R.; McGillivary, G.; Sherratt, D.J.; Actis, L.A.; Tolmasky, M.E. Complete nucleotide sequence of Klebsiella pneumoniae multiresistance plasmid pJHCMW1. Antimicrob. Agents Chemother. 2002, 46, 3422-3427. [CrossRef]

41. Arciszewska, L.K.; Baker, R.A.; Hallet, B.; Sherratt, D.J. Coordinated control of XerC and XerD catalytic activities during Holliday junction resolution. J. Mol. Biol. 2000, 299, 391-403. [CrossRef]

42. Colloms, S.D.; McCulloch, R.; Grant, K.; Neilson, L.; Sherratt, D.J. Xer-mediated site-specific recombination in vitro. EMBO J. 1996, 15, 1172-1181. [CrossRef] [PubMed]

43. Riley, M.; Abe, T.; Arnaud, M.B.; Berlyn, M.K.; Blattner, F.R.; Chaudhuri, R.R.; Glasner, J.D.; Horiuchi, T.; Keseler, I.M.; Kosuge, T.; et al. Escherichia coli K-12: A cooperatively developed annotation snapshot-2005. Nucleic Acids Res. 2006, 34, 1-9. [CrossRef]

44. Martinez, J.; Fernandez, J.S.; Liu, C.; Hoard, A.; Mendoza, A.; Nakanouchi, J.; Rodman, N.; Courville, R.; Tuttobene, M.R.; Lopez, C.; et al. Human pleural fluid triggers global changes in the transcriptional landscape of Acinetobacter baumannii as an adaptive response to stress. Sci. Rep. 2019, 9, 17251. [CrossRef]

45. Tran, T.; Sherratt, D.J.; Tolmasky, M.E. fpr, a deficient Xer recombination site from a Salmonella plasmid, fails to confer stability by dimer resolution: Comparative studies with the pJHCMW1 mwr site. J. Bacteriol. 2010, 192, 883-887. [CrossRef]

46. Acosta, J.; Merino, M.; Viedma, E.; Poza, M.; Sanz, F.; Otero, J.R.; Chaves, F.; Bou, G. Multidrug-resistant Acinetobacter baumannii Harboring OXA-24 carbapenemase, Spain. Emerg. Infect. Dis. 2011, 17, 1064-1067. [CrossRef] [PubMed]

47. Larouche, A.; Roy, P.H. Effect of attC structure on cassette excision by integron integrases. Mob DNA 2011, 2, 3. [CrossRef] [PubMed]

48. Escudero, J.A.; Loot, C.; Nivina, A.; Mazel, D. The Integron: Adaptation on demand. Microbiol. Spectr. 2015, 3, MDNA3-0019-2014.

49. Vallenet, D.; Nordmann, P.; Barbe, V.; Poirel, L.; Mangenot, S.; Bataille, E.; Dossat, C.; Gas, S.; Kreimeyer, A.; Lenoble, P.; et al. Comparative analysis of Acinetobacters: Three genomes for three lifestyles. PLoS ONE 2008, 3, e1805. [CrossRef]

50. Blakely, G.; Sherratt, D. Determinants of selectivity in Xer site-specific recombination. Genes Dev. 1996, 10, 762-773. [CrossRef]

51. Grainge, I.; Bregu, M.; Vazquez, M.; Sivanathan, V.; Ip, S.C.; Sherratt, D.J. Unlinking chromosome catenanes in vivo by site-specific recombination. EMBO J. 2007, 26, 4228-4238. [CrossRef] [PubMed]

52. Shimokawa, K.; Ishihara, K.; Grainge, I.; Sherratt, D.J.; Vazquez, M. FtsK-dependent XerCD-dif recombination unlinks replication catenanes in a stepwise manner. Proc. Natl. Acad. Sci. USA 2013, 110, 20906-20911. [CrossRef]

53. Isler, B.; Doi, Y.; Bonomo, R.A.; Paterson, D.L. New treatment options against carbapenem-resistant Acinetobacter baumannii infections. Antimicrob. Agents Chemother. 2019, 63, e01110-e01118. [PubMed]

54. Hartstein, A.I.; Rashad, A.L.; Liebler, J.M.; Actis, L.A.; Freeman, J.; Rourke, J.W., Jr.; Stibolt, T.B.; Tolmasky, M.E.; Ellis, G.R.; Crosa, J.H. Multiple intensive care unit outbreak of Acinetobacter calcoaceticus subspecies anitratus respiratory infection and colonization associated with contaminated, reusable ventilator circuits and resuscitation bags. Am. J. Med. 1988, 85, 624-631. [CrossRef]

55. Summers, D.K.; Sherratt, D.J. Resolution of ColE1 dimers requires a DNA sequence implicated in the three-dimensional organization of the cer site. EMBO J. 1988, 7, 851-858. [CrossRef] [PubMed]

56. Cornet, F.; Mortier, I.; Patte, J.; Louarn, J.M. Plasmid pSC101 harbors a recombination site, psi, which is able to resolve plasmid multimers and to substitute for the analogous chromosomal Escherichia coli site dif. J. Bacteriol. 1994, 176, 3188-3195. [CrossRef]

57. Spiers, A.J.; Sherratt, D.J. Relating primary structure to function in the Escherichia coli XerD site-specific recombinase. Mol. Microbiol. 1997, 24, 1071-1082. [CrossRef]

58. Ramirez, M.S.; Don, M.; Merkier, A.K.; Bistue, A.J.; Zorreguieta, A.; Centron, D.; Tolmasky, M.E. Naturally competent Acinetobacter baumannii clinical isolate as a convenient model for genetic studies. J. Clin. Microbiol. 2010, 48, 1488-1490. [CrossRef] 
59. Traglia, G.M.; Chua, K.; Centron, D.; Tolmasky, M.E.; Ramirez, M.S. Whole-genome sequence analysis of the naturally competent Acinetobacter baumannii clinical isolate A118. Genome Biol. Evol. 2014, 6, 2235-2239. [CrossRef]

60. Yanisch-Perron, C.; Vieira, J.; Messing, J. Improved M13 phage cloning vectors and host strains: Nucleotide sequences of the M13mp18 and pUC19 vectors. Gene 1985, 33, 103-119. [CrossRef]

61. Chang, A.C.; Cohen, S.N. Construction and characterization of amplifiable multicopy DNA cloning vehicles derived from the P15A cryptic miniplasmid. J. Bacteriol. 1978, 134, 1141-1156. [CrossRef] [PubMed]

62. Cohen, S.N.; Chang, A.C.; Hsu, L. Nonchromosomal antibiotic resistance in bacteria: Genetic transformation of Escherichia coli by R-factor DNA. Proc. Natl. Acad. Sci. USA 1972, 69, 2110-2114. [CrossRef] [PubMed]

63. Blakely, G.; May, G.; McCulloch, R.; Arciszewska, L.K.; Burke, M.; Lovett, S.T.; Sherratt, D.J. Two related recombinases are required for site-specific recombination at dif and cer in E. coli K12. Cell 1993, 75, 351-361. [CrossRef]

64. Nunes-Duby, S.E.; Radman-Livaja, M.; Kuimelis, R.G.; Pearline, R.V.; McLaughlin, L.W.; Landy, A. Gamma integrase complementation at the level of DNA binding and complex formation. J. Bacteriol. 2002, 184, 1385-1394. [CrossRef]

65. Summers, D. Timing, self-control and a sense of direction are the secrets of multicopy plasmid stability. Mol. Microbiol. 1998, 29, 1137-1145. [CrossRef] [PubMed]

(C) 2020 by the authors. Licensee MDPI, Basel, Switzerland. This article is an open access article distributed under the terms and conditions of the Creative Commons Attribution (CC BY) license (http://creativecommons.org/licenses/by/4.0/). 